УДК 538.9

\title{
Day Plots of Bacterial Magnetite from Sediments of Shira Lake (Khakassia, Russia)
}

\section{Sergey V.Semenov* \\ Dmitry A. Balaev}

Kirensky Institute of Physics SB RAS Akademgorodok, 50/38, Krasnoyarsk, 660036

Siberian Federal University

Svobodny, 79, Krasnoyarsk, 660041

Russia

Kirill A. Shaykhutdinov

Kirensky Institute of Physics SB RAS Akademgorodok, 50/38, Krasnoyarsk, 660036

Russia

Denis Yu. Rogozin

Institute of Biophysics SB RAS

Akademgorodok, 50/50, Krasnoyarsk, 660036

Siberian Federal University

Svobodny, 79, Krasnoyarsk, 660041

Russia

Received 10.08.2016, received in revised form 10.11.2016, accepted 20.01.2017

The domain state of magnetite detected in sediments of Shira lake (Khakassia, Russia) was examined by means of magnetic hysteresis. Analysis of experimental data obtained on samples from different parts of bottom sediment cores in terms of Day plots allowed us to conclude that magnetite particles are in the pseudo-single-domain state. This indicates respectively small size of magnetite particles ( $<100 \mathrm{~nm}$ ) and reveals their bacterial origin. Biogenic magnetite buried in the bottom sediments can indicate the climatic changes in the Shira lake level in the Late Holocene.

Keywords: nanoparticles, magnetic hysteresis, bacterial magnetite.

DOI: 10.17516/1997-1397-2017-10-2-252-256.

\section{Introduction}

One of crucial factors determining magnetic hysteresis of submicron size particles is the type of their domain state. Among the single-domain (SD) and multi-domain (MD) states the intermediate between SD and MD, so called pseudo-single-domain (PSD) state is distinguished. These domain states are conventionally elucidated in terms of Day plots [1]. In this report the domain state of magnetite detected in sediments of Shira lake (Khakassia, Russia) was examined by means of analysis of magnetization curve $\mathrm{M}(\mathrm{H})$ measurements. The aim was to confirm (or to disconfirm) the bacterial origin of magnetite in sediments of Shira lake obtained from previous

*smp@iph.krasn.ru

(c) Siberian Federal University. All rights reserved 
study [2]. In [2] the non-monotonic dependence of magnetite content on the depth of sediments was found to correlate with the lake level indicating that the most probable source of magnetite is magnetosomes of magnetotactic halolimnetic bacteria.

\section{Experimental}

Lake Shira $\left(54^{\circ} 30^{\prime} \mathrm{N}, 90^{\circ} 11^{\prime} \mathrm{E}\right)$ is located in the Chebakovo-Balakhtinskaya depression of the Minusinsk trough, a steppe region of the Republic of Khakassia (Siberia, Russia) was described in detail elsewhere [3]. The bottom sediments were sampled on May 31, 2011 in the central part of Lake Shira at $54^{\circ} 30.546^{\prime} \mathrm{N}$ and $90^{\circ} 11.442^{\prime} \mathrm{E}$. The lake depth of the sampling area was 24 $\mathrm{m}$. The sampling was made with the use of an Ekman box bottom grab taking a bottom area of 160x160 mm. The samples were cut from several parts of bottom sediment cores (obtained in 2011) corresponded to different depths (in $\mathrm{mm}$ ) of sediments. Magnetic measurements were performed by using vibration sample magnetometer. A signal from the sample with a capsule was corrected by the diamagnetic signal from the capsule; then, the magnetic moment was normalized to the unit sample mass.

\section{Results and discussion}

The Fig. 1 shows typical field dependence of magnetization $\mathrm{M}(\mathrm{H})$ for sediment sample. Hysteresis of the $\mathrm{M}(\mathrm{H})$ dependence in the field range up to $2 \mathrm{kOe}$ is seen. Another feature of the $\mathrm{M}(\mathrm{H})$ dependence is its linear behavior in the range of fields higher than $2 \mathrm{kOe}$. The slope of this linear dependence was found to decrease with increasing of temperature. The inset of Fig. 1 shows the temperature dependence of magnetic moment $\mathrm{M}(\mathrm{T})$ of the sample measured in the external field of $1 \mathrm{kOe}$. There is a a kink on the $\mathrm{M}(\mathrm{T})$ dependence at temperature of $120 \mathrm{~K}$ corresponding to the Vervey transition of magnetite. The decrease of the magnetization with temperature is due to additional paramagnetic contribution from $\mathrm{Fe}^{2+}$ and $\mathrm{Fe}^{3+}$ ions [2]. This paramagnetic (PM) contribution was taken into account and the ferrimagnetic (FM) contribution (from magnetite) was extracted from $\mathrm{M}(\mathrm{H})$ and $\mathrm{M}(\mathrm{T})$ data, see the Fig. 1.

To build the Day plots a set of minor hysteresis curve with step by step increase of the maximal applied field Hmax (up to Hmax corresponding to the major loop) were recorded. The values of remanence $\mathrm{M}_{R}$, saturation magnetization $\mathrm{M}_{S}$, coercivity $\mathrm{H}_{C}$, and $\mathrm{H}_{C R}\left(\mathrm{H}_{C R}\right.$ corresponds to the Hmax value at which the remanence is 0.5 of the $\mathrm{M}_{R}$ magnitude for the major loop) were determined from these data. The Fig. 2 shows major and minor hysteresis $\mathrm{M}(\mathrm{H})$ curves together with typical example of determination of $\mathrm{M}_{R}, \mathrm{M}_{R S}, \mathrm{H}_{C}$, and $\mathrm{H}_{C R}$ values. The experimental data obtained on several samples from different depths of sediments were plotted in the co-ordinates $\mathrm{M}_{R S} / \mathrm{M}_{S}, \mathrm{H}_{C R} / \mathrm{H}_{C}$. According to [1] the SD, PSD, and MD states correspond to areas shown in the Fig. 3. As can be seen from this figure the experimental data obtained on samples from various depths are located in the PSD region. This indicates respectively small size of magnetite particles $(<100 \mathrm{~nm})[4]$ and reveals their bacterial origin.

\section{Conclusions}

Thus, the magnetic state of the magnetite particles buried in the sediments of the Shira lake is the pseudo-single-domain. This points out the small size $(<100 \mathrm{~nm})$ of the magnetite 


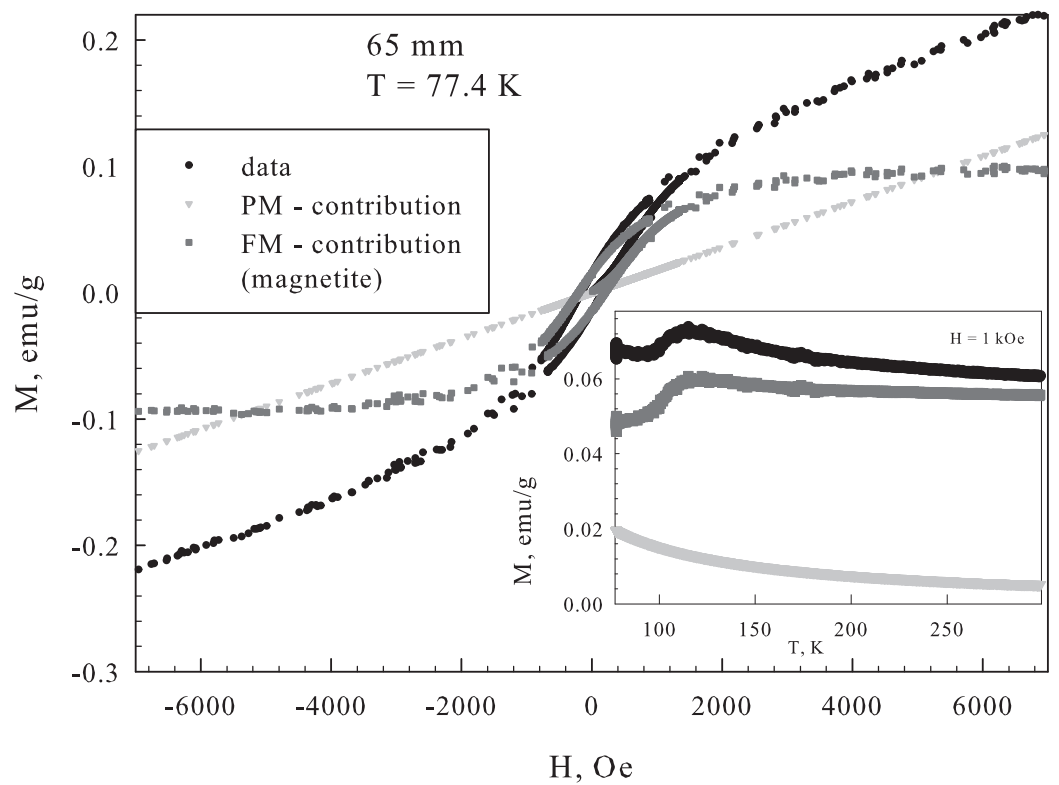

Fig. 1. Typical results of magnetic measurements of a sediment at the depth of $65 \mathrm{~mm}$ together with FM and PM contributions

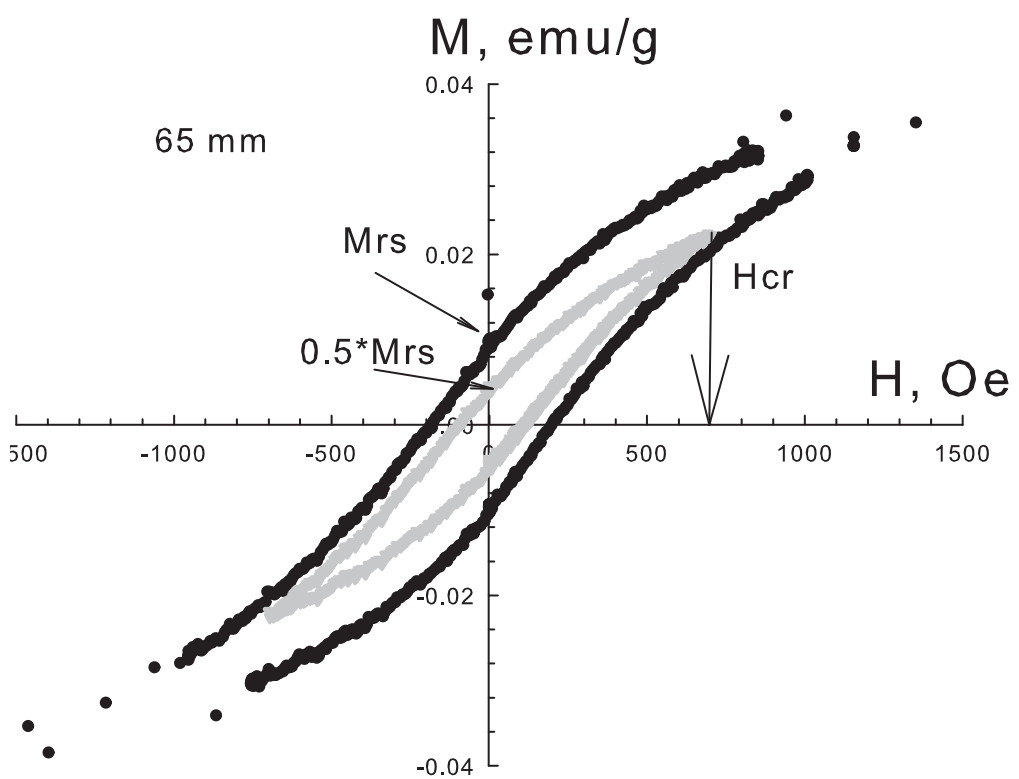

Fig. 2. Typical major and minor hysteresis magnetization curves of a sediment at the depth of $65 \mathrm{~mm}$ 


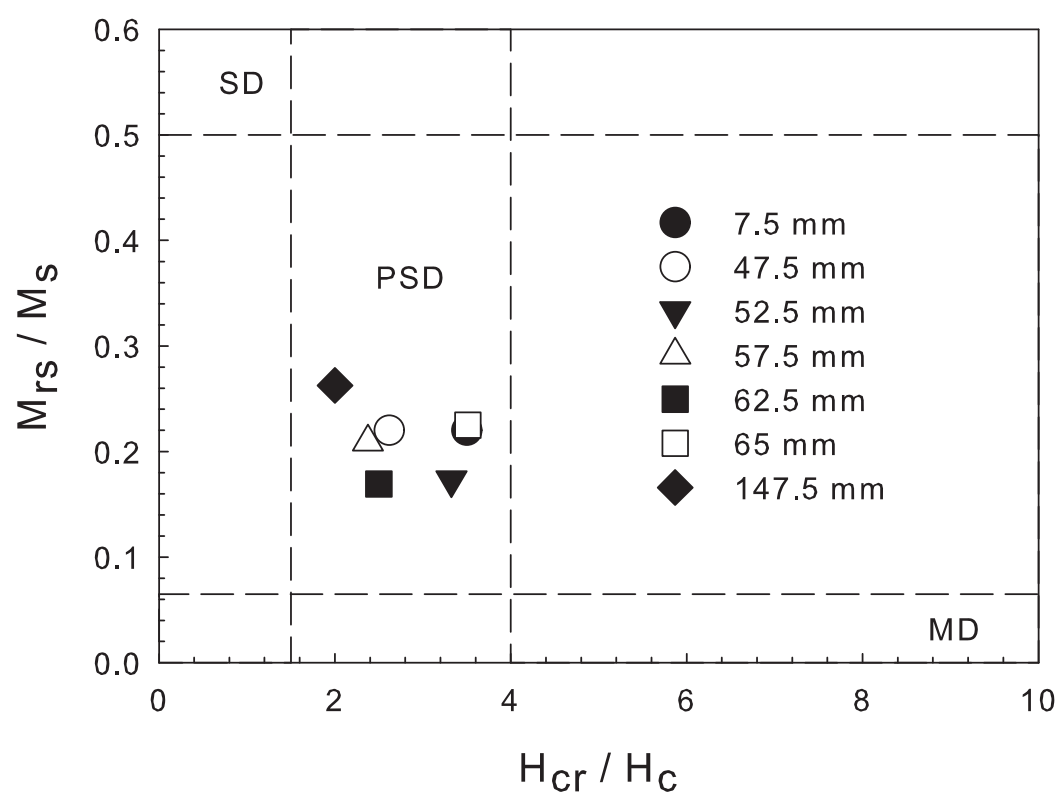

Fig. 3. The Day plots for the studied samples from the sediments of various depths

particles and supports the conclusion of Ref. [2] that the source of magnetite in the sediments is magnetosomes of magnetotactic halolimnetic bacteria. Therefore, biogenic magnetite buried in the bottom sediments can indicate the climatic changes in the Shira lake level in the Late Holocene.

The work was supported by Russian Foundation for Basic Research and Krasnoyarsk Regional Scientific Foundation, Grant no. 15-45-04272 and partially supported by the Council on grants from the President of the Russian Federation for support of leading scientific schools (grant NSh9249.2016.5)

\section{References}

[1] R.Day et al, Hysteresis properties of titanomagnetites: grain-size and compositional dependence, Physics of the Earth and Planetary Interiors, 13(1977), 260-267.

[2] D.Yu.Rogozin, D.A.Balaev, S.V.Semenov, K.A.Shaikhutdinov, O.A.Bayukov, Magnetic Properties of Bottom Sediments from Meromectic Shira Lake (Siberia, Russia), Doklady Earth Sciences, 469(2016), 819-823.

[3] A.G.Degermendzhy, et al, Vertical stratification of physical, chemical and biological components in two saline lakes Shira and Shunet (South Siberia, Russia), Aquatic Ecology, 44(2010), 619-632.

[4] D.Sarkar et al, Domain controlled magnetic and electric properties of variable sized magnetite nano-hollow spheres, J. Appl. Phys., 112(2012), 064318. 


\section{Графики Дэя для бактериального магнетита из донных отложений озера Шира (Хакасия, Россия)}

\section{Сергей В. Семёнов \\ Дмитрий А. Балаев}

Институт физики им. Л. В. Киренского СО РАН

Академгородок, 50/38, Красноярск, 660036

Россия

Кирилл А. Шайхутдинов

Институт физики им. Л. В. Киренского СО РАН

Академгородок, 50/38, Красноярск, 660036

Денис Ю. Рогозин

Институт биофизики СО РАН

Академгородок, 50/50, Красноярск, 660036

Россия

Исследовано доменное состояние магнетита, обнаруженного в донных отложениях озера Шира (Хакасия, Россия). Из анализа экспериментальных данных по намагниченности образцов с разных участков керна донных отложений, а также на основе графиков Дэя сделан вывод, что частицы магнетита находятся в псевдооднодоменном состоянии. Это указывает на малый размер частии магнетита (<100 nm) и подтверждает их бактериальное происхождение. Биогенный магнетит, содержащийся в донных отложениях, может служить индикатором климатических изменений в уровне озера Шира в позднем голочене.

Ключевые слова: наночастицы, магнитный гистерезис, бактериалъный магнетит. 